\title{
Correction to: Computational assembly of a human Cytomegalovirus vaccine upon experimental epitope legacy
}

Monica J. Quinzo ${ }^{1}$, Esther M. Lafuente ${ }^{1}$, Pilar Zuluaga ${ }^{1}$, Darren R. Flower ${ }^{2}$ and Pedro A. Reche ${ }^{1 *}$

\section{Correction to: BMC Bioinformatics}

https://doi.org/10.1186/s12859-019-3052-6

After publication of the original article [1], we were notified that legends of Fig. 1 and Fig. 2 have been swapped.

Below the legends are correctly related to the figures.

\section{Author details}

${ }^{1}$ Faculty of Medicine, University Complutense of Madrid, Pza Ramon y Cajal,

s/n, 28040 Madrid, Spain. ${ }^{2}$ School of Life and Health Sciences, Aston

University, Aston Triangle, Birmingham B4 7ET, UK.

Published online: 19 March 2020

\section{Reference}

1. Quinzo, et al. Computational assembly of a human Cytomegalovirus vaccine

upon experimental epitope legacy. BMC Bioinformatics. 2019;20(Suppl 6):

476. https://doi.org/10.1186/s12859-019-3052-6.

The original article can be found online at https://doi.org/10.1186/s12859019-3052-6

* Correspondence: parecheg@med.ucm.es

From 2nd International Workshop on Computational Methods for the Immune System Function Madrid, Spain. 3-6 December 2018

${ }^{1}$ Faculty of Medicine, University Complutense of Madrid, Pza Ramon y Cajal, s/n, 28040 Madrid, Spain

Full list of author information is available at the end of the article

(c) The Author(s). 2020 Open Access This article is licensed under a Creative Commons Attribution 4.0 International License, which permits use, sharing, adaptation, distribution and reproduction in any medium or format, as long as you give appropriate credit to the original author(s) and the source, provide a link to the Creative Commons licence, and indicate if changes were made. The images or other third party material in this article are included in the article's Creative Commons licence, unless indicated otherwise in a credit line to the material. If material is not included in the article's Creative Commons licence and your intended use is not permitted by statutory regulation or exceeds the permitted use, you will need to obtain permission directly from the copyright holder. To view a copy of this licence, visit http://creativecommons.org/licenses/by/4.0/. The Creative Commons Public Domain Dedication waiver (http://creativecommons.org/publicdomain/zero/1.0/) applies to the data made available in this article, unless otherwise stated in a credit line to the data. 


\section{IEDB DATABASE}

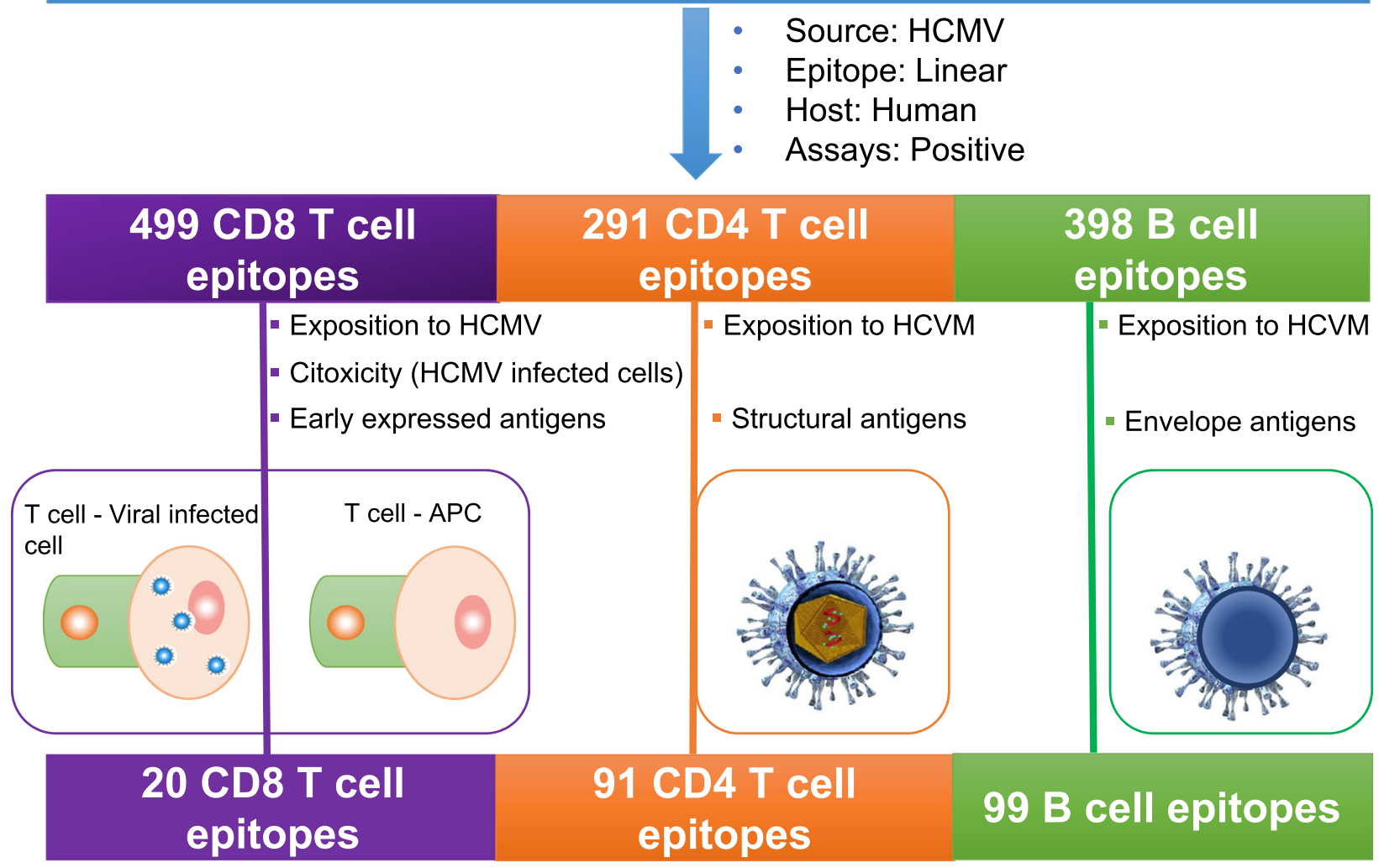

\section{Knowledge-based Epitope selection for vaccine design}

Fig. 1 Knowledge-based selection of experimental epitopes for HCMV vaccine design. Experimental epitopes were obtained from IEDB and selected to identify those that are more likely to induce protective immunity in humans. CD8 T cell epitopes were identified upon searches that guarantee that were processed and presented early by APCs (immunogen exposition) and by target cells (mediate cytotoxic activity of cells infected with HCMV). CD4 T cell epitopes were selected for being recognized by HCMV exposed subjects and belonging to structural proteins, so that they will provide early effective help. B cell epitopes were also selected for being recognized by HCMV exposed subjects and mapping onto the ectodomain of envelope proteins so that they can induce neutralizing antibodies 


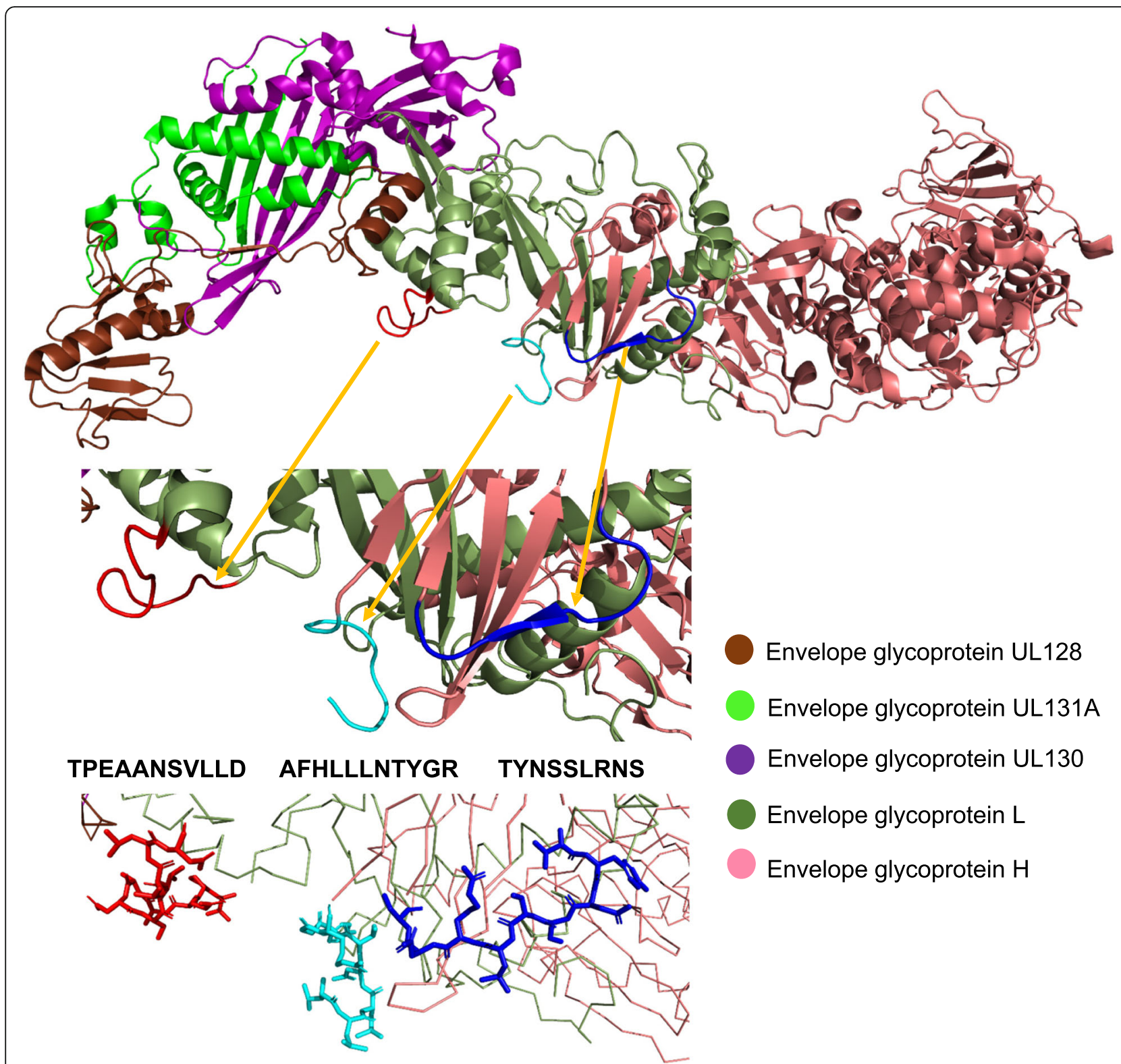

Fig. 2 Mapping of predicted (purple and blue) and experimentally defined (red) B cell epitopes on the tertiary structure of the $\mathrm{gH}$ and $\mathrm{gL}$ as part of the pentameric complex L75/UL115/UL128/UL130/UL131A. B cell epitopes are respresented as sticks over a background of ribbons 